\title{
Nutritional Composition, Sensory Profile and Consumer Acceptability of Wheat-Jackfruit Seed Composite Buns
}

\author{
Sarah S Ngwere ${ }^{1,2}$ and Richard J Mongi ${ }^{2}, 3^{*}$ \\ ${ }^{I}$ Cereals and Other Produce Board, P. O. Box 9524, Dodoma, Tanzania. \\ E-mail:ngweresudi@gmail.com \\ ${ }^{2}$ Department of Food Technology, Nutrition and Consumer Sciences, Sokoine University of \\ Agriculture, P. O. Box 3006, Morogoro Tanzania. \\ ${ }^{3}$ Department of Public Health, University of Dodoma, P. O. Box 395, Dodoma, Tanzania. \\ *Corresponding author,e-mail: richiemongi@gmail.com
}

Received 15 Feb 2021, Revised 23 July 2021, Accepted 28 Jul 2021, Published Aug 2021

DOI: https://dx.doi.org/10.4314/tjs.v47i3.24

\begin{abstract}
Jackfruit seeds flour is very rich in nutrients and may be incorporated into wheat flour to develop nutrient dense baked products. Consumption of these products may improve the nutrition status of the people, hence fulfill sustainable development goal number two. In this study, nutritional composition, sensory profile, and consumer acceptability of wheat-jackfruit seeds composite buns (Mandazi) were investigated. Jackfruit seeds flour (JSF) was developed and incorporated into wheat flour (WF) at 10,20, and 30\% to produce composite flour used for bun preparation. Flours and buns were subjected to proximate, mineral, and sensory analyses with WF serving as a control sample. JSF had significantly $(\mathrm{p}<0.05)$ higher protein, fibre and mineral contents than wheat flour. Proximate and mineral contents increased significantly $(\mathrm{p}<0.05)$ in bun samples with increasing levels of WF substitution in the formulations. As for sensory analysis, whole wheat control buns and $10 \%$ composite buns had significantly $(\mathrm{p}<0.05)$ higher crumb colour, softness, sweetness and consumer acceptability but lower colour intensity than 20 and $30 \%$ composite buns. Therefore, incorporation of JSF up to $10 \%$ into WF produces composite buns with enhanced nutritional contents and similar sensory profile and consumer acceptability to whole wheat flour.
\end{abstract}

Keywords: Jackfruit seed, Nutritional composition, Sensory profile, Composite buns.

\section{Introduction}

Jackfruit (Artocarpus heterophyllus Lam) is the largest known edible fruit in the world. It belongs to the family Moraceae which originated in India and Malaysia and is currently found in many parts of Asia, South America, and Africa (Swami et al. 2015, Amadi et al. 2018). Worldwide, Bangladesh, India and Myanmar are among the major jackfruit producing countries (Sidhu 2012, Selva Rani et al. 2019). In Tanzania, the fruit is locally grown in limited areas of Zanzibar, Tanga, Coast, and Morogoro regions
(Mushumbusi 2015). Jackfruit seed that represents $15-18 \%$ of the fruit weight is a good source of proteins, fibres, starch (Roy Chowdhury et al. 2012, Waghmare et al. 2019), and many minerals such as potassium, phosphorus, calcium, magnesium, zinc, and copper (Maurya and Mogra 2016, Zuwariah et al. 2018). Furthermore, the seeds have various health befits to human beings such as antiinflammatory, antioxidant, antiulcer, and antidiabetic activities which are linked to the phytochemicals and other bioactive compounds 
they contain (Ranasinghe et al. 2019, Adan et al. 2020, Sreeja Devi et al. 2021).

However, despite their high nutritional value and health benefits, jackfruit is still underutilized and highly perishable due to insufficient processing knowledge and resources in the regions where it is grown (Ranasinghe et al. 2019) including Tanzania. The seeds are discarded as waste because no studies have been conducted to explore their potential as a food ingredient in diet and industrial application. According to Adan et al. (2020) and Banarjee and Datta (2015), the seeds may be processed into flour and incorporated into wheat flour to produce composite bakery products and confectionery like cake, bread, and buns. Composite flour technology has been used to enhance the nutritional and functional properties of flour and its processed products in an economical way (Oke et al. 2019, Hasmadi et al. 2020). The technology has been used as a food based approach for curbing malnutrition especially in low-income countries where malnutrition is alarming (Bain et al. 2013).

Buns (mandazi) are among the most common baked food products mostly used for breakfast and in some cases for lunch in Tanzania. Due to rapid changes in the lifestyles of people that have led to an increase in the number of bakeries and fast-food restaurants, buns are now easily available in many places in town including shops, supermarkets, and bus stopovers and on the streets. The inclusion of jackfruit into wheat flour will result in buns with enhanced nutritional values and their consumption in the right amounts may improve nutrition outcomes of people in the society. This is in line with sustainable development goal number two which seeks to end hunger and improve the nutrition of people among other objectives (United Nations 2015). Despite adequate literature review, information on the nutrition composition, sensory profile, and consumer acceptability of jackfruit seed and wheat composite flour buns was missing. This study was therefore conducted to establish and avail the missing information.

\section{Materials and Methods Materials}

Mature and fresh jackfruits were purchased from local farmers in Kinole and Makuyuni villages in Morogoro Region. Morogoro Region was purposively selected as it is one of the famous regions for growing jackfruits in Tanzania. A high quality, commercial grade soft winter wheat patent flour, yeast (instant dry yeast), fat, baking powder, and sugar were purchased from local shops in Morogoro. Analytical food grade reagents and chemicals were obtained at the Departments of Food Technology, Nutrition and Consumer Sciences (DFTNCS) and Soil Sciences (DSS) laboratories at Sokoine University of Agriculture (SUA) in Morogoro Region where chemical and sensory analyses were conducted.

\section{Research designs}

A completely randomized design (CRD) was applied for the assessment of the chemical composition of the products. The formulation was the main factor and its effects on proximate and mineral contents of jackfruit flour and composite buns were assessed and compared. The mathematical model is shown in Equation 1.

$$
Y_{I J}=\mu+\alpha_{I J} \ldots \ldots \ldots \ldots . . \text { Equation } 1
$$

Where $\mu$ is the overall (grand) mean, $\alpha_{\mathrm{i}}$ is the effect due to the $\mathrm{i}^{\text {th }}$ treatment (formulation), and $\varepsilon_{i j}$ is the error term.

Randomized complete block design (RCBD) was used to assess the sensory profile and acceptability. Panelists and formulations were the principal factors. The mathematical model is shown in Equation 2.

$$
Y_{I J}=\mu+\beta_{I J}+\alpha_{I J} \ldots \ldots \ldots \ldots \text { Equation } 2
$$

Where $\mu$ is the overall (grand) mean, $\alpha_{i}$ is the effect due to the $i^{\text {th }}$ treatment (formulation), $\beta j$ is the effect due to the $\mathrm{j}^{\text {th }}$ block (panelists) and $\varepsilon_{i j}$ is the error term.

\section{Preparation of jackfruit seed flour (JSF)}

Flour and composite flours were prepared following a method described by Roy Chowdhury et al. (2012) with slight 
modifications. The fruits were washed with clean water to remove dirt and cut into two halves, the seeds were removed, cleaned with water and pre-dried using a clean piece of cloth. The seed coats were manually peeled off using a knife before the seeds sliced into thin chips using a knife, and then solar dried using a walk-in direct solar dryer at $40{ }^{\circ} \mathrm{C}$ for 2 days until they attained constant weight and predetermined moisture content of $10 \%$. The dried seeds were milled to flour using a milling machine (Model N/50, $650 \mathrm{~kg} /$ hour, Small Industries Development Organization (SIDO), Tanzania) and were packed into a polythene bag and stored in a refrigerator $\left(<10{ }^{\circ} \mathrm{C}\right)$ before composite flour preparation.

\section{Preparation of wheat-JSF composite flours (WJCFs)}

The wheat-jackfruit composite flours were processed by blending wheat and jackfruit seed flours at different levels of wheat flour substitutions. Ten (10), twenty (20) and thirty (30) parts by weight of jackfruit seed flour were mixed with ninety (90), eighty (80) and seventy (70) parts by weight of wheat flour to obtain 10, 20, and $30 \%$ of jackfruit-wheat composite flours, respectively. The processed flours were packed in a polythene bag and stored at $5{ }^{\circ} \mathrm{C}$ before buns preparations.

\section{Preparation of buns}

The whole-wheat (WWB) and wheat jackfruit seed flour composite buns (WJCBs) were made by mixing the flours with weighed ingredients to obtain a uniform mixture as indicated in Table 1. Water was added gradually into the mixture, and the mixture was kneaded into a soft dough. The dough was left to leaven at 27 ${ }^{\circ} \mathrm{C}$ for 45 minutes and then cut into small pieces of the desired shapes by using a knife and left to stay for 10 minutes. Pieces of dough were deep-fried in hot sunflower oil at $150{ }^{\circ} \mathrm{C}$ until the golden-brown colour was attained. Buns were removed from hot oil, kept in a metal sieve to drain the oil, and left to cool on a clean plate at room temperature. The cooled buns were preserved in a food-grade polyethylene bag and stored in a refrigerator $(<$ $10{ }^{\circ} \mathrm{C}$ ) before chemical and sensory analyses.

Table 1: Composition of wheat-jackfruit seed buns

\begin{tabular}{lcccc}
\hline Ingredients & \multicolumn{4}{c}{ Formulation (\%) } \\
\hline & WFB & WJCF 1 & WJCF 2 & WJCF 3 \\
\cline { 2 - 5 } Wheat flour \% $(\mathrm{g})$ & $100(500)$ & $90(450)$ & $80(400)$ & $70(350)$ \\
Jackfruit flour \% $(\mathrm{g})$ & $0(0)$ & $10(50)$ & $20(100)$ & $30(150)$ \\
Baking powder $(\mathrm{g})$ & 3.5 & 3.5 & 3.5 & 3.5 \\
Fat $(\mathrm{g})$ & 10 & 10 & 10 & 10 \\
Sugar $(\mathrm{g})$ & 65 & 65 & 65 & 65 \\
Salt $(\mathrm{g})$ & 1.5 & 1.5 & 1.5 & 1.5 \\
\hline
\end{tabular}

\section{Chemical analyses}

Proximate analysis

Proximate composition of the flours and buns were determined using the Association of Official Analytical Chemists (AOAC 2005) standard procedure. Moisture content was determined by oven drying (Method 925.10), fat by Soxhlet extraction (Method 2003.05), ash by combustion (Method 923.03), crude fibres by dilute acid, and alkali hydrolysis
(Method 978.0) and proteins by micro Kjeldahl method (Method 960.52). A conversion factor of $\mathrm{N}=6.02$ was used for the calculation of protein content. The carbohydrate content was determined by calculation using the different method (AOAC 2005). Each proximate parameter was analyzed in triplicate and computations were based on a dry weight basis. 


\section{Determination of mineral contents}

The ash content was used for the analysis of the minerals according to the AOAC (2005) procedures. The ash was dissolved in $20 \mathrm{ml}$ of $1 \mathrm{~N} \mathrm{HCl}$ and heated for 5 minutes at $80-90{ }^{\circ} \mathrm{C}$. The solute was then transferred quantitatively to a $100 \mathrm{ml}$ volumetric flask and made to level with distilled water. Calcium and magnesium were determined by Atomic Absorption Spectrometer (AAS) (Unicam 919, Pye Unicam, England). Potassium was determined using a flame photometer (flame analyzer) and phosphorus was determined using a UV-Vis spectrophotometer at $722 \mathrm{~nm}$ (AOAC 2005). Each sample was analyzed in triplicate and quantification was accomplished by comparison with a standard curve drawn using a standard solution of known concentrations at $0.5,1.00,1.5$, and $2.5 \mathrm{ppm}$. The mineral content was expressed using the formula shown in Equation 3.

Mineral content $(\mathrm{Mg} / 100 \mathrm{~g})=\frac{\mathrm{R} \times 100 \times \mathrm{DF} \times 100}{\mathrm{~S} \times 1000}$

where $\mathrm{R}$ is reading value (in ppm), DF is a dilution factor and $\mathrm{S}$ is a sample weight $(\mathrm{g})$.

\section{Sensory analysis \\ Quantitative descriptive analysis (QDA)}

Quantitative descriptive analysis was conducted at the Department of Food, Nutrition and Consumer Science laboratory involving a trained panel of 8 assessors (3 male and 5 female) with ages ranging from 23 to 30 years according to the method described by Lawless and Heymann (2010). Assessors were selected and trained according to ISO method 8586 (2012). During training, panelists developed and agreed on the seven attributes aroma, crumb colour, crust colour, mouthfeel, oiliness, softness, and sweetness as shown in (Table 2). Assessors also developed and agreed on an unstructured 10-line scale which was used for rating the intensity of the agreed attributes with the left side corresponding to the lowest intensity of each attribute (value 1) and the right side corresponding to the highest intensity (value 10). All samples were coded with 3 -digit random numbers and served to each panelist in a randomized order. The average responses obtained from the panelist were used in the univariate and multivariate analyses. Panel performance to ascertain panelists' agreement, discrimination ability, and reproducibility were done during a pre-trial session of the training.

Table 2: Definitions of sensory attributes used in descriptive sensory analysis

\begin{tabular}{lll}
\hline Parameter & Attribute & Definition \\
\hline Aroma & Wheat bun aroma & Aromatic associated with bun \\
Crust colour & Brown hue & Brown colour associated with bun crust \\
Crumb colour & White hue & Cream white colour associated with bun crumb \\
& Colour intensity & Clear, strong colour \\
Oily & Oiliness & Amount oiliness exuded in the bun \\
Taste & Sweetness & The taste associated with sucrose solution \\
Texture & Softness & The force to compress a sample via first compression \\
& & (The force required to bite through the sample) \\
& Mouthfeel & Stickiness feeling when chewing bun
\end{tabular}

Source: Study panelists

\section{Consumer test}

Acceptability test: Acceptability test was conducted by 70 untrained consumers using a 9-point hedonic scale (where $1=$ dislike extremely and $9=$ like extremely) as described by Lawless and Heymann (2010). Buns samples were cut into small pieces of $2 \mathrm{~mm}$, placed on disposable plates coded with threedigit random numbers and the plates were served to the panelists in a randomized manner. 
All good sensory practices such as consideration of the testing environment, sample, and panelist as well as testing protocol such as sample labeling, serving as well as rinsing mouth between tests were carefully observed to avoid biases.

\section{Statistical data analysis}

Data were analyzed by R statistical package ( $R$ Development Core Team, Version 3.0.0 Vienna, Austria) for Analysis of Variance (ANOVA) to determine the significant differences in proximate composition, mineral contents, sensory attributes intensities, and consumer acceptability of flours and their composite buns. Means were separated using Tukey's Honest Significant Difference ( $\mathrm{p}<$ 0.05). Principal Component Analysis (PCA) was used to determine the systematic variations in sensory data using Latentix Software (LatentiX Aps Team, version 2.12,
Frederiksberg Denmark). Results were presented as arithmetic mean values and standard deviations in Tables and graphs as well as in PCA biplots.

\section{Results and Discussion \\ Proximate composition of flours and buns}

Results for the proximate composition of wheat and jackfruit seed flours and buns are shown in Table 3. Jackfruit seed flour had significantly $(\mathrm{p}<0.05)$ higher protein, ash, and fibre contents than lower values in wheat flour. This results in a significant $(\mathrm{p}<0.05)$ and progressive increase in the same proximate parameters in bun samples as the wheat flour substitution increased in the formulations. However, jackfruit flour had lower fat contents than wheat flour resulting in significant $(\mathrm{p}<$ 0.05 ) lower values in composite buns as the jackfruit seed flour levels increased in the formulation (Table 3).

Table 3: Proximate composition of flours and composite buns (g/100 g DM)

\begin{tabular}{lcccccc}
\hline Sample & Moisture & Ash & Fat & Protein & Fibre & CHO \\
\hline Flour & & & & & & \\
\hline Wheat & $11.6 \pm 0.28^{\mathrm{a}}$ & $0.4 \pm 0.02^{\mathrm{b}}$ & $1.0 \pm 0.2^{\mathrm{a}}$ & $8.5 \pm 0.24^{\mathrm{b}}$ & $1.4 \pm$ & $82.3 \pm$ \\
& & & & $0.31^{\mathrm{b}}$ & $0.64^{\mathrm{a}}$ \\
Jackfruit & $9.5 \pm 0.24^{\mathrm{b}}$ & $3.4 \pm 0.33^{\mathrm{a}}$ & $0.9 \pm 0.4^{\mathrm{a}}$ & $13.3 \pm 0.07^{\mathrm{a}}$ & $5.1 \pm$ & $67.8 \pm$ \\
& & & & $1.16^{\mathrm{a}}$ & $1.63^{\mathrm{b}}$ \\
Buns & & & & & \\
\hline WFB (100) & $20.5 \pm 1.31^{\mathrm{a}}$ & $0.3 \pm 0.01^{\mathrm{d}}$ & $31.4 \pm 0.03^{\mathrm{a}}$ & $5.9 \pm 0.07^{\mathrm{c}}$ & $1.5 \pm$ & $40.4 \pm$ \\
& & & & $0.00^{\mathrm{c}}$ & $0.05^{\mathrm{b}}$ \\
WJCB 1 & $18.4 \pm 0.64^{\mathrm{ab}}$ & $0.9 \pm 0.02^{\mathrm{c}}$ & $28.8 \pm 0.11^{\mathrm{b}}$ & $6.2 \pm 0.00^{\mathrm{b}}$ & $1.6 \pm$ & $44.1 \pm$ \\
$(90: 10)$ & & & & $0.00^{\mathrm{c}}$ & $0.78^{\mathrm{ab}}$ \\
WJCB 2 & $17.9 \pm 0.00 \mathrm{a}^{\mathrm{b}}$ & $1.3 \pm 0.03^{\mathrm{b}}$ & $27.5 \pm 0.48^{\mathrm{c}}$ & $6.5 \pm 0.07^{\mathrm{b}}$ & $2.3 \pm$ & $44.6 \pm$ \\
$(80: 20)$ & & & & & & \\
& & & & & & \\
WJCB 3 & $15.6 \pm 0.28^{\mathrm{b}}$ & $1.5 \pm 0.00^{\mathrm{a}}$ & $26.7 \pm 0.08^{\mathrm{c}}$ & $7.1 \pm 0.07^{\mathrm{a}}$ & $2.9 \pm$ & $0.59^{\mathrm{ab}}$ \\
$(70: 30)$ & & & & & $0.02^{\mathrm{a}}$ & $0.27^{\mathrm{a}}$ \\
\hline
\end{tabular}

Values are expressed as mean \pm SD $(n=3)$. Mean values with different letters along the columns are significantly different at $\mathrm{p}<0.05$. Key: WFB is a wheat flour bun and WJCB is a wheat jackfruit seed composite bun.

Jackfruit seed flour contains high amounts of ash, proteins, and fibres as previously reported by Zubair et al. (2017) and Ranasinghe et al. (2019). Their increased levels in composite flours therefore could be associated with high levels of these nutrients in buns samples. A similar increase in ash, protein and fibre contents was previously reported in composite chapatti (Sultana et al. 2014), composite cake (Khan et al. 2016), and composite chocolate cake (Arpit and John 2015). Contrarily, the observed decrease in fat content in composite buns may be attributed to low fat contents in jackfruit seed flour coupled with reduced fat 
absorption up to a certain limit making good components of the fat free diet (Butool and Butool 2015, Zubair et al. 2017). However, Sultana et al. (2014) and Islam (2015) observed an increase in fat contents from 1.03 to $1.67 \mathrm{~g}$ in wheat jackfruit composite chapatti and biscuits, respectively.

\section{Mineral composition of flours and buns}

Table 4 shows that jackfruit seed flour had significantly $(\mathrm{p}<0.05)$ higher values for all minerals than wheat flour, with potassium ranking as the highest. This resulted in a progressive increase in mineral contents in the composite buns as their proportions increased in the formulations. However, no significant ( $p$ $>0.05)$ differences in calcium and magnesium contents between wheat and $10 \%$ buns were observed.

Table 4: Mineral contents of flours and composite buns at different levels of wheat flour substitution (mg/100 g DM)

\begin{tabular}{lcccc}
\hline Samples & Calcium & Magnesium & Potassium & Phosphorus \\
\hline Flours & & & & \\
Wheat & $13.4 \pm 0.07^{\mathrm{e}}$ & $14.5 \pm 0.07^{\mathrm{b}}$ & $137.5 \pm 0.71^{\mathrm{e}}$ & $79.8 \pm 0.74^{\mathrm{e}}$ \\
Jackfruit & $68.4 \pm 0.70^{\mathrm{a}}$ & $161.6 \pm 0.25^{\mathrm{a}}$ & $1454.4 \pm 1.39^{\mathrm{a}}$ & $301.7 \pm 2.26^{\mathrm{a}}$ \\
Formulations & & & \\
WFB (100) & $38.3 \pm 1.31^{\mathrm{c}}$ & $21.3 \pm 0.01^{\mathrm{c}}$ & $136.7 \pm 0.03^{\mathrm{a}}$ & $138.6 \pm 0.07^{\mathrm{c}}$ \\
WJCB 1 (90:10) & $41.4 \pm 0.64^{\mathrm{b}}$ & $21.0 \pm 0.02^{\mathrm{c}}$ & $176.3 \pm 0.11^{\mathrm{b}}$ & $147.2 \pm 0.00^{\mathrm{b}}$ \\
WJCB 2 (80:20) & $46.1 \pm 0.00 \mathrm{a}^{\mathrm{a}}$ & $30.3 \pm 0.03^{\mathrm{b}}$ & $240.1 \pm 0.48^{\mathrm{c}}$ & $159.3 \pm 0.07^{\mathrm{b}}$ \\
WJCB 3 (70:30) & $49.8 \pm 0.28^{\mathrm{a}}$ & $38.7 \pm 0.00^{\mathrm{a}}$ & $312.0 \pm 0.08^{\mathrm{c}}$ & $165.6 \pm 0.07^{\mathrm{a}}$ \\
\hline
\end{tabular}

Values are expressed as mean \pm SD $(n=3)$. Mean values with different superscript letters along the columns are significantly different at $\mathrm{p}<0.05$. Key WFB is wheat flour and WJCB is wheat jackfruit seed composite bun.

Jackfruit flour is rich in potassium phosphorus, calcium, magnesium, zinc, and copper than wheat flour (Abedin et al. 2012). The higher values in flour resulted in a progressive increase in mineral contents in the composite buns similar to the findings reported by Airani (2007) in jackfruit flour composite biscuits. The high amounts of minerals in composite buns are very important in the human diet and normal body health. Potassium is an essential nutrient needed for the maintenance of total body fluid volume, acid and electrolyte regulation, nerve function, muscle control, and blood pressure (Bellows and Moore 2013, Weaver 2013). World Health Organization (WHO 2012) recommends an increase in potassium intake $(3510 \mathrm{mg} /$ day $)$ from food to reduce blood pressure and risk of cardiovascular disease, stroke, and coronary heart disease in adults (WHO 2012). This means one needs to consume up to $2 \mathrm{~kg}$ /day of $10 \%$ composite buns to meet the requirement suggesting consumption of other potassium rich foods. The seeds contain an abundance of magnesium which plays a vital role in lowering blood pressure and maintaining bone health since it aids in calcium absorption and hence helps to strengthen the bones (Maurya and Mogra 2016).

\section{Sensory analysis Quantitative descriptive analysis}

Table 5 presents the mean intensity scores of different sensory attributes of bun samples. Control whole wheat and $10 \%$ composite bun samples had significantly ( $\mathrm{p}<0.05$ ) lower crust hue but higher mean crumb hue, sweetness, and intensities than 20 and $30 \%$ composite bun samples. On the other hand, higher mean crust hue intensity of 7.9 was observed in the $30 \%$ composite sample than the lowest value of 7.17.2 in control and $10 \%$ composite bun samples. 
Table 5: Mean intensity scores of wheat and jackfruit seed flour composite buns

\begin{tabular}{llllllll}
\hline Sample & $\begin{array}{l}\text { Crust } \\
\text { hue }\end{array}$ & $\begin{array}{l}\text { Crumb } \\
\text { hue }\end{array}$ & Sweetness & Aroma & Mouthfeel & Oiliness & Softness \\
\hline WFB (100) & $7.2 \pm$ & $7.5 \pm$ & $6.9 \pm$ & $6.7 \pm$ & $7.4 \pm$ & $7.6 \pm$ & $7.3 \pm$ \\
& $1.72^{\mathrm{b}}$ & $1.82^{\mathrm{a}}$ & $1.77^{\mathrm{a}}$ & $2.09^{\mathrm{a}}$ & $1.78^{\mathrm{a}}$ & $1.09^{\mathrm{a}}$ & $1.53^{\mathrm{a}}$ \\
WJCB 1 & $7.1 \pm$ & $6.3 \pm$ & $6.8 \pm$ & $6.1 \pm$ & $6.3 \pm$ & $6.9 \pm$ & $6.4 \pm$ \\
$(90: 10)$ & $1.71^{\mathrm{b}}$ & $2.18^{\mathrm{ab}}$ & $1.60^{\mathrm{a}}$ & $2.31^{\mathrm{b}}$ & $2.12^{\mathrm{b}}$ & $1.61^{\mathrm{b}}$ & $1.75^{\mathrm{ab}}$ \\
WJCB 1 & $7.6 \pm$ & $5.8 \pm$ & $6.0 \pm$ & $6.1 \pm$ & $6.2 \pm$ & $6.8 \pm$ & $5.0 \pm$ \\
$(90: 20)$ & $1.54^{\mathrm{ab}}$ & $2.32^{\mathrm{bc}}$ & $2.13^{\mathrm{b}}$ & $2.16^{\mathrm{b}}$ & $2.46^{\mathrm{b}}$ & $1.95^{\mathrm{b}}$ & $1.15^{\mathrm{c}}$ \\
WJCB 1 & $7.9 \pm$ & $4.6 \pm$ & $5.6 \pm$ & $5.6 \pm$ & $5.6 \pm$ & $6.2 \pm$ & $4.0 \pm$ \\
$(90: 30)$ & $1.5^{\mathrm{a}}$ & $3.00^{\mathrm{c}}$ & $2.25^{\mathrm{c}}$ & $2.31^{\mathrm{c}}$ & $2.55^{\mathrm{c}}$ & $1.72^{\mathrm{c}}$ & $1.31^{\mathrm{d}}$ \\
\hline
\end{tabular}

Values are expressed as mean \pm SD $(n=10)$. Mean values with different superscript letters along the columns are significantly different at $p<0.05$. Key: WFB is wheat flour bun and WJCB is wheat jackfruit seed composite bun.

Furthermore, the biplot of principal component analysis (Figure 1) shows that PC 1 accounts for $97.6 \%$ of the total variability and it is a contrast between control and $10 \%$ composite samples related to all attributes except crust colour on one side and $20-30 \%$ composite samples associated with crust colour on the other side. PC 2 accounts for only $2 \%$ of total variability and it is a contrast between $10 \%$ composite sample associated with sweetness and softness on one side and the other samples on the other side.

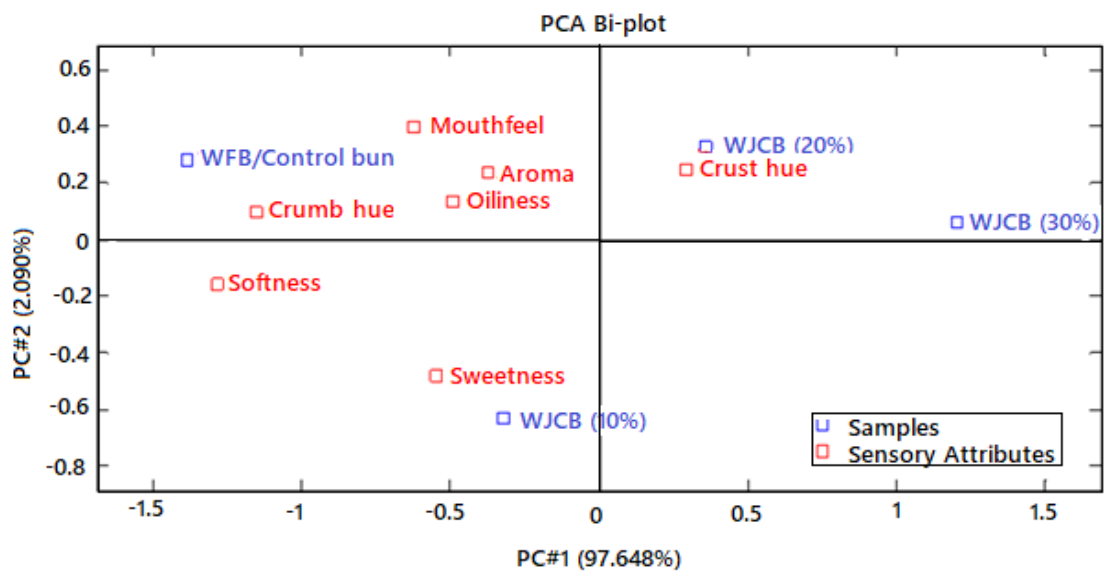

Figure 1: Principal component analysis biplot for sensory data. Key: WFB is a wheat flour bun and WJCB is a wheat jackfruit seed composite bun.

Substitution of wheat flour with jackfruit seed flour at $20 \%$ and above affects the sensory profile of the bun samples. The reported lower intensities in all sensory attributes except crust colour as the level of jackfruit seed flour increased in the formulations may be associated with the addition of non-wheat flour as previously reported in wheat-orange fleshed sweet potato composite buns (Mongi et al. 2015) and wheat jackfruit composite biscuits (Islam et al. 2015). High brown crust colour and low white crumb intensities in 20 and 30\% composite samples could be associated with increased light brown jackfruit seeds flour in the formulations and composite products. Jackfruit seed is surrounded by a brown outer 
covering (spermoderm) that affected the colour of its flour (Prakash et al. 2009). In addition, the deep crust colour may be associated with the Maillard reaction between reducing sugars and amino acids in the flours (Phisut and Jiraporn 2013). This finding is in agreement with previous findings by Hossain (2014) that the addition of more than $25 \%$ jackfruit seed flour in bread led to a change in colour from light brown to dark brown. Colour is one of the quality criteria for the initial acceptability, purchasing, and consumption of the baked product by the consumers.

\section{Consumer test}

\section{Consumer panel characteristics}

Consumer panel comprised of 40 panelists whereby $26(75 \%)$ were males and $14(25 \%)$ were females. All (100\%) panelists were University undergraduate students in the age group of 20-27 years pursuing different programs with $24(60 \%)$ of them were frequent users of buns on daily basis, $8(20 \%)$ consumed once a week, $5(12.5 \%)$ consumed once per month and $3(7.5 \%)$ were seldom users of buns as indicated in Table 6.

Table 6: Characteristics of the consumer acceptability panel $(\mathrm{n}=40)$

\begin{tabular}{llrr}
\hline Attribute & Category & Frequency $(\mathrm{n})$ & Percentage (\%) \\
\hline Gender & Male & 26 & 75 \\
& Female & 14 & 35 \\
Age group & Total & $\mathbf{4 0}$ & $\mathbf{1 0 0}$ \\
& $19-30$ & 40 & 100 \\
Education group & $31-40$ & 0 & 0 \\
& Total & $\mathbf{4 0}$ & $\mathbf{1 0 0}$ \\
& Undergraduate & 40 & 100 \\
Consumption & Postgraduate & 0 & 0 \\
& Total & $\mathbf{4 0}$ & $\mathbf{1 0 0}$ \\
& Daily & 24 & 60 \\
& Once/week & 8 & 20 \\
& Once/month & 5 & 12.5 \\
& Seldom & 3 & 7.5 \\
& Total & $\mathbf{4 0}$ & $\mathbf{1 0 0}$ \\
\hline
\end{tabular}

\section{Consumer acceptability}

Whole wheat and $10 \%$ bun samples had statistically $(\mathrm{p}>0.05)$ higher mean hedonic values which differed significantly $(\mathrm{p}<0.05)$ from 20 and $30 \%$ composite bun samples as depicted in Figure 2. No significant $(\mathrm{p}>0.05)$ variation was observed between the control and $10 \%$ composite buns.

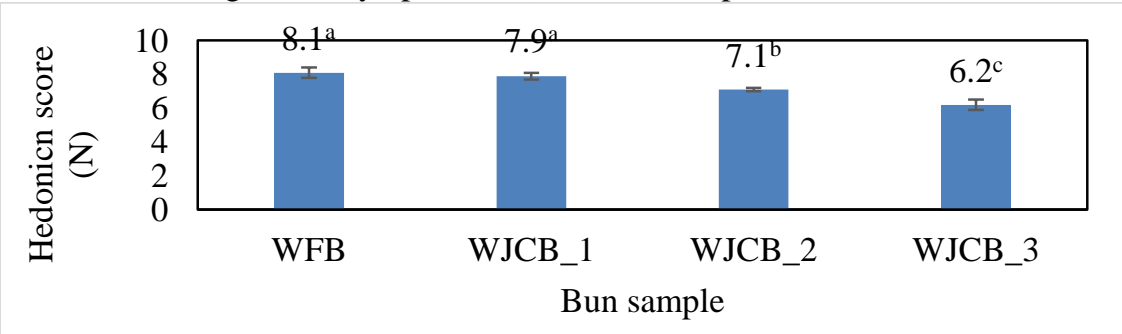

Figure 2: Mean hedonic scores of control and composite buns samples. Values are expressed as mean \pm SD $(n=60)$. Bars with mean values with different letters are significantly different at $\mathrm{p}<0.05$. Key: WFB is a wheat flour bun and WJCB is a wheat jackfruit composite bun. 
The fact that consumers could not establish the significant variation between control and $10 \%$ composite samples suggests that jackfruit seed flour up to $10 \%$ may be incorporated into wheat flour to produce buns with comparable consumer acceptability as whole wheat buns. Beyond this level, sensory characteristics, and consumer acceptability may be affected. Low acceptability of composite samples as substitution of wheat flour increases in the formulations could be ascribed to high addition of non-wheat flour which affects sensory profiles and consequently consumer acceptability as observed in the current and previous studies (Mongi et al. 2015, Islam et al. 2015, and Butool and Butool 2015). The present study revealed that jackfruit seed flour has a great potential for the development of new bakery food products along with wheat flour as reported in other studies. Sultana et al. (2017) developed nutrient-dense wheat jackfruit seed flour composite cakes, while David (2016) and Amin (2009) developed nutritious jackfruit seed flour chocolate cake. Furthermore, Hossain et al. (2014) developed wheat jackfruit seed floor composite bread, and Hasan et al. (2010) prepared biscuits from jackfruit seed flour blended with wheat flour.

\section{Conclusion}

In a view of the findings, jackfruit seed flour has more proteins, fibres, ash, carbohydrates, calcium, magnesium, potassium, and phosphorus than wheat flour. Substitution of wheat flour with jackfruit flour at different levels enhances protein, ash, fibre calcium, magnesium, potassium, and phosphorus contents of the processed composite flour and the resulting buns. The control whole wheat buns (100\% wheat) had high sensory attribute intensities except for crust colour. Moreover, there was no significant difference in overall consumer acceptability between control whole wheat bread and $10 \%$ composite bun samples. Therefore, the present study revealed that jackfruit seed flour is nutritious and its incorporation of up to $10 \%$ into wheat flour produces composite buns with enhanced nutritional contents and similar sensory profile and consumer acceptability to whole wheat flour.

\section{Acknowledgments}

The authors are grateful to the Department of Food Technology, Nutrition and Consumer Sciences and Department of Soil Science laboratories of Sokoine University of Agriculture (SUA) for giving access to their laboratory for chemical and sensory analyses.

\section{Conflict of interest: None.}

\section{References}

Abedin MS Nuruddin, MM Ahmed KU and Hossain A 2012 Nutritive compositions of locally available Jackfruit seeds (Artocarpus heterophyllus) in Bangladesh. Int. J. Biosci. 2(8): 1-7.

Adan AA, Ojwang RA, Muge EK, Mwanza BK and Nyaboga EN 2020 Phytochemical composition and essential mineral profile, antioxidant and antimicrobial potential of unutilized parts of jackfruit. Food Res. 4(4): 1125-1134.

Airani S 2007 Nutritional quality and value addition to jackfruit seed flour. MSc Dissertation University of Agricultural Sciences, Dharwad.

Amadi JAC, Austin I and Afam-Anene OC 2018 Nutrient and phytochemical composition of Jackfruit (Artocarpus heterophyllus) Pulp, seeds and leaves. Int. J. Innov. Food. Nut. Sust. Agric. 6(3): 2732.

Amin MFS 2009 Optimization of jackfruit seed (Artocarpus heterophyllus LAM.) flour and polydextrose content in the formulation of reduced calorie chocolate cake. MSc Dissertation University of Sabah.

AOAC (Association of Official Analytical Chemists) 2005 Official Methods of Analysis-17 $7^{\text {th }}$ ed. Association of Official Analytical Chemists, Washington, D.C. USA.

Arpit S and John D 2015 Effects of different levels of jackfruit seed flour on the quality 
characteristics of chocolate cake. J. Agric. Forest. Sci. 3 (11): 6-9.

Bain LE, Awah PK, Geraldine N, Kindong NP, Sigal Y, Bernard N, Tanjeko AT 2013 Malnutrition in Sub-Saharan Africa: burden, causes and prospects. Pan Afr. Med. J. 15: 120.

Banarjee S and Datta S 2015 Effect of dry heat-treated jackfruit seed powder on the growth of experimental animals. Int. $J$. Pharm. Biol. Sci. 10(6): 42-46.

Bellows L and Moore R 2013 Potassium and the Diet. Food and Nutrition Series|Health. Fact Sheet No. 9.355. Colorado State University

[https://extension.Colostate.edu/ Extension docs/pubs/foodnut/09355.pdf] Site visited on 11.02.2020

Butool S and Butool M 2015 Nutritional quality on value addition to jack fruit seed flour. Int. J. Sci. Res. 4: 2406-2411.

Roy Chowdhury A, Bhattacharyya AK and Chattopadhyay P 2012 Study on functional properties of raw and blended jackfruit seed flour (a non-conventional source) for food application. Indian J. Nat. Prod. Resour. 3(3): 347-353.

David J 2016 Antioxidant properties of fibre rich dietetic chocolate cake developed by jackfruit (Artocarpus heterophyllus L.) seed flour. Int. J. Food Eng. 2(2): 132-135.

Hasan SMK, Hossain MA, Hossain MJ, Roy J and Sarker MSH 2010 Preparation of biscuits from jackfruit (Artocarpus heterophyllus) seed flour blended with wheat flour. The Agriculturists 8 (1):10-18.

Hasmadi M, Noorfarahzilah M, Noraidah H, Zainol MK and Jahurul MHA 2020 Functional properties of composite flour. A review. J. Food Res. 4(6): 1820-1831.

Hossain MT, Hossain MM, Sarker M, Shuvo AN, Alam MM and Rahman MS 2014 Development and quality evaluation of bread supplemented with jackfruit seed flour. Int. J. Nutr. Food Sci. 3(5): 484-487.

ISO 85862012 Sensory analysis-General guidelines for the selection, training, and monitoring of selected assessors and expert sensory assessors 8586 (E). Geneva Switzerland.

Islam S, Begum R, Khatun $\mathrm{M}$ and Dey $\mathrm{KC}$ 2015 A study on nutritional and functional properties analysis of jackfruit seed flour and value addition to biscuits. Int. J. Eng. Res. Technol. 4 (12): 139-147.

Khan SA, Saqib MN and Alim MA 2016 Evaluation of quality characteristics of composite cake prepared from mixed jackfruit seed flour and wheat flour. $J$ Bangladesh Agric. Univ. 14 (2): 219-227.

Lawless TH and Heymann H 2010 Sensory evaluation of foods: principles and practices. $2^{\text {nd }}$ Edition, Springer New York, USA.

Maurya P and Mogra R 2016 Assessment of consumption practices of jackfruit (Artocarpus heterophyllus lam.) seeds in villages of Jalalpur block District Ambedarnagar ( Uttar Pradesh) India. $A d v$. Life Sci. 5(5): 168-1644.

Mongi RJ, Simbano M, Ruhembe C and Majaliwa N 2015 Development and assessment of frying characteristics, chemical composition, descriptive sensory properties, and preference mapping of wheat-orange fleshed sweet potato composite swahili buns (maandazi). Tanz. J. Agric. Sci. 14(2): 129-142.

Mushumbusi DG 2015 Production and characterization of jackfruit jam. MSc Dissertation, Sokoine University of Agriculture.

Oke EK, Idowu MA, Sobukola OP and Bakare HA 2019 Quality attributes and storage stability of bread from wheat-tigernut composite flour. J. Culinary Sci. Technol. 17(1): 75-88.

Phisut N and Jiraporn B 2013 Characteristics and antioxidant activity of maillard reaction products derived from chitosan-sugar solution. Int. Food Res. J. 20(3): 10771085.

Prakash RO, Mishra KA and Gupta R 2009 Artocarpus heterophyllus (Jackfruit): An overview. Pharmacognosy Rev. 3(6): 353358. 
Ranasinghe RASN, Maduwanthi SDT and Marapana RAUJ 2019 Nutritional and health benefits of jackfruit (Artocarpus heterophyllus Lam.): a review. Int. J. Food Sci. 2019: 1-12.

Selva Rani N, Raja M and Suresh M 2019 Quality evaluation of musk melon seeds flour and jackfruit seeds flour for bakery products development. J. Pharma Innov. Int. J. 8(6): 703-706.

Sidhu AS 2012 Jackfruit improvement in the Asia-Pacific Region-A status report. AsiaPacific Association of Agricultural Research Institutions, Bangkok, Thailand.

Sreeja Devi PS, Kumar NS and Sabu KK 2021 Phytochemical profiling and antioxidant activities of different parts of Artocarpus heterophyllus Lam. (Moraceae): A review on current status of knowledge. Futur J. Pharm. Sci. 7: 30.

Sultana A, Amin MN, Miah MY, Sarker AK, Rasel MA, Aziz MT, Sharmin F, Abdul Hakim A, Shiddika H, Emon SH, Tuli PT and Khanom MM 2017 Determination of proximate composition and amino profile of jackfruit seed and utilization of its seed flour for development of protein enriched supplementary food. Cell Biol. 5(60): 5765.

Sultana A, Rahman RT, Islam M, Rahman M and Alim A 2014 Evaluation of quality of chapaties enriched with jackfruit seed flour and bengal gram flour. J. Environ. Sci. Toxicol. Food Technol. 8(5): 73-78.

Swami SB, Thako RNJ, Haldankar PM and Kalse SB 2012 Jackfruit and its many functional components as related to human health: a review. Compr. Rev. Food Sci. Food Saf. 11: 565-576.

United Nations 2015 Transforming our world: The 2030 agenda for sustainable development.

A/RES/70/1[https://sdgs.un.org/sites/defaul t/files/publications/21252030\%20Agenda\% 20for\%20Sustainable\%20Development $\% 20$ web.pdf] Site visited on 18.06.2021

Weaver CM 2013 Potassium and health. $A d v$. Nutr. 4(3): 368-377.

Waghmare R, Memon N, Gat Y, Gandhi S, Kumar V and Panghal A 2019 Jackfruit seed: an accompaniment to functional foods. Braz. J. Food Technol. 22: 1-9.

WHO (World Health Organization) 2012 Effect of increased potassium intake on cardiovascular disease, coronary heart disease, and stroke. Geneva.

[http://apps.who.int/iris/bitstream/handle/10665 /79334/9789241504867_eng.pdf?sequence $=1]$ Site visited on 10.12.2020

Zubair A, Esita, FA, Haque A, Akter J, Abedin Z and Sikder A 2017 Nutrient composition and quality evaluation of composite bread with jackfruit (Artocarpus heterophyllus) seed flour. Res. Rev.: J. Food Sci. Technol. 6(2): 40-48.

Zuwariah I, Noor Fadilah MB, Hadijah H and Rodhiah R 2018 Comparison of amino acid and chemical composition of jackfruit seed flour treatment. Food Res. 2(6): 539-545. 